\title{
Diaminobenzene schiff base, a novel class of DNA minor groove binder
}

\author{
MUATH H. HELAL ${ }^{1}$, ZENA A. AL-MUDARIS ${ }^{1}$, MOHAMMED H. AL-DOUH ${ }^{2,3}$, HASNAH OSMAN $^{2}$, \\ HABIBAH A. WAHAB ${ }^{1}$, BELAL O. ALNAJJAR ${ }^{1}$, HASSAN H. ABDALLAH ${ }^{2}$ and AMIN M.S. ABDUL MAJID ${ }^{1}$ \\ ${ }^{1}$ Department of Pharmacology, School of Pharmaceutical Sciences, ${ }^{2}$ School of Chemical Sciences, \\ Universiti Sains Malaysia, 11800 Penang, Malaysia
}

Received August 21, 2011; Accepted December 19, 2011

DOI: 10.3892/ijo.2012.1491

\begin{abstract}
Molecules that target the deoxyribonucleic acid (DNA) minor groove are relatively sequence specific and they can be excellent carrier structures for cytotoxic chemotherapeutic compounds which can help to minimize side effects. Two novel isomeric derivatives of diaminobenzene Schiff base $[N, N$-bis (2-hydroxy-3-methoxybenzylidene)-1,2-diaminobenzene (2MJ) and $N, N^{\prime}$-bis(2-hydroxy-3-methoxybenzylidene)-1,3-diaminobenzene $(2 \mathrm{MH})$ ] were analyzed for their DNA minor groove binding (MGB) ability using viscometry, UV and fluorescence spectroscopy, computational modeling and clonogenic assay. The result shows that $2 \mathrm{MJ}$ and $2 \mathrm{MH}$ are strong DNA MGBs with the latter being more potent. $2 \mathrm{MH}$ can form interstrand hydrogen bond linkages at its oxygens with $\mathrm{N} 3$ of adenines. Changing the 2-hydroxy-3-methoxybenzylidene binding position to the 1,3 location on the diaminobenzene structure $(2 \mathrm{MJ})$ completely removed any viable hydrogen bond formation with the DNA and caused significant decrease in binding strength and minor groove binding potency. Neither compound showed any significant cytotoxicity towards human breast, colon or liver cancer cell lines.
\end{abstract}

\section{Introduction}

Chemotherapeutic agents that directly target the DNA can do so in a variety of ways including alkylation, intercalation, groove binding and disruption of enzymes that govern its topology. The manner, in which these agents interact, has significant biological implications that may affect their therapeutic outcome. Agents that associate non-covalently with the nucleic acid either by groove binding or intercalation, have been shown to be more selective towards specific DNA sequences (1). Such agents

Correspondence to: Dr A.M.S Abdul Majid, Department of Pharmacology, School of Pharmaceutical Sciences, Universiti Sains Malaysia, Minden, 11800 Penang, Malaysia

E-mail: aminmalikshah@usm.my

Present address: ${ }^{3}$ Chemistry Department, Faculty of Science, Hadhramout University of Science \& Technology (HUST), POBox: 50511 or 50512, Mukalla, Hadhramout, Republic of Yemen

Key words: Schiff base, intercalators, minor groove binders, deoxyribonucleic acid, cytotoxin, cancer can serve as carrier structures to deliver alkylating agents and hence improve potency but with reduced side effects. Minor groove binders have better ability to discriminate between DNA sequences than intercalators. DNA intercalators tend to target major groove regions of the oligonucleotide that are rich in GC sequences (2). They are also generally more cytotoxic partly due to their influence on topoisomerase enzyme activity (2). Intercalators have planar structures and can slide in between adjoining DNA bases (3). This enables relatively strong binding by stacking interaction between adjacent base pairs through electrostatic forces (4). The strong attraction to the DNA polymer give intercalators potent biological effect making them an important class of chemotherapeutic agent (4). The binding interaction can also be enhanced by increasing the chromophore size and introducing specific structures that can slow down the dissociation kinetics which will allow the drug longer time within the DNA vicinity hence improving drug potency (4).

Amongst the many molecular configurations of MGBs, the arc-shaped conformer has the best structural feature that can insert itself snugly into the DNA minor groove forming hydrogen bonds between the available hydrogen bond donors and acceptors (5). A good MGB has positive charge on one or both ends of its structure which draws it to the negative electrostatic charges present on the floor of the minor groove region of the DNA (1).

Schiff base compounds $\left(\mathrm{R}_{1} \mathrm{R}_{2} \mathrm{C}=\mathrm{N}-\mathrm{R}_{3}\right.$ where $\mathrm{R}$ is aryl/alkyl), also known as azomethines can form complexes with transition metals and consequently have wide applications in corrosion science $(5,6)$. They were reported to have anti-bacterial (7-9) and anti tumor properties (10). Studies on Schiff base interaction with the nucleic acid is limited with most work focusing on metal complex of this compound $(11,12)$. Their mode of interaction with DNA varies depending on the structure, with some compounds showing good intercalative ability with significant anti-tumor property (12). A number of these Schiff base metal complexes were able to penetrate into the groove region (13) while others caused DNA strand cleavage (14).

Schiff bases can be synthesized from aromatic amines and carbonyl compounds through nucleophilic addition reaction forming a hemiaminal via tetrahedral mechanism. This is further dehydrated to form an imine derivative (15-17). We have synthesized two bis-Schiff base compounds $(2 \mathrm{MJ})$ and $(2 \mathrm{MH})$ and solved their crystal structures (Fig. 1A and B) (15-19). The rigid $\mathrm{C}=\mathrm{N}$ structure, the flat aromatic moiety and the presence 
of imine moieties in both compounds allow a wide variety of structural analogues to be prepared.

In this study we analyze the suitability of these two bis-Schiff base compounds as potential MGBs. We probed the nature of their binding characteristics so as to understand structural features that are important for good binding efficiency between diaminobenzene Schiff base and DNA. With this in mind, these two Schiff base structural analogues, which differ in their 2-hydroxy3-methoxybenzylidene binding position, were employed in this study. 2MJ (Fig. 1A) has its 2-hydroxy-3-methoxybenzylidene substructure located at the 1 and 2 positions of its diaminobenzene unit, while $2 \mathrm{MH}$ (Fig. 1B), has this moiety located at the 1 and 3 positions making its structure wider than the former.

\section{Materials and methods}

Calf thymus DNA, $\mathrm{MgCl}_{2}, \mathrm{NaCl}$, phosphate buffer, EtBr, dimethyl sulfoxide (DMSO) solvent, trypsin and Hoechst 33258 were all purchased from Sigma-Aldrich (St. Louis, MO, USA). For the cytotoxicity work; human breast ductal carcinoma (T-74D), human colon carcinoma (HCT-116), human hepatocellular carcinoma (HepG2) cells were all sourced from ATCC (American Type Cell Culture). Fetal bovine serum, McCoy's 5A, minimum essential medium (MEM) and RPMI1641 medium were acquired from Life Technologies (CA, USA). 3-[4,5-dimethylthiazol-2-yl]-2,5-diphenyltetrazolium bromide (MTT) was purchased from PhytoTechnology Laboratories (KS, USA). 2MJ and 2MH were synthesized in our laboratory according to previous published methods (18-20).

Standard buffer solution containing $0.15 \mathrm{M} \mathrm{NaCl}, 0.50 \mathrm{mM}$ $\mathrm{MgCl}_{2}$, and $10.00 \mathrm{mM}$ phosphate buffer ( $\mathrm{pH}$ 7.3) was used throughout (20)]. Schiff base compounds were separately dissolved in ethanol forming $1000 \mu \mathrm{M}$ stock solutions. Stock solution of calf thymus DNA was prepared by dissolving $4.57 \mathrm{mg}$ of the calf thymus in $1.50 \mathrm{ml}$ of the standard buffer solution.

The procedure was performed according to previous published work (21). Briefly, $30 \mu \mathrm{l}$ of each drug was added to $500 \mu \mathrm{l}$ buffer and the absorption was measured. Thirty $\mu \mathrm{l}$ were taken from $2 \mathrm{MJ}$ and diluted to $500 \mu \mathrm{l}$ using the same standard buffer. UV absorbance was measured at 200-550 nm wavelengths. The DNA stock solution was titrated against the respective drug solution. The absorbance measurement was taken after each addition of DNA in order to calculate the intrinsic binding constant for each compound with the nucleic acid. The volumes of DNA added to $2 \mathrm{MJ}$ solution were $2,4,6,8,15,20,30,50,80$ and $130 \mu \mathrm{l}$ to give effective DNA concentration of 0.003, 0.006, 0.009, 0.012, 0.022, $0.03,0.045,0.075,0.12,0.195 \mathrm{mg} / \mathrm{ml}$, respectively. The DNA was added until no apparent decrease in absorption reading was observed. This procedure was repeated for $2 \mathrm{MH}$, using the 2 , $4,6,8,10,12,14,16,22$ and $30 \mu 1$ of the DNA stock solution to give $0.003,0.006,0.009,0.012,0.015,0.018,0.021,0.024,0.033$, $0.045 \mathrm{mg} / \mathrm{ml}$ solution. The UV absorbance values were measured on a USA Perkin-Elmer Lambda 45 spectrometer.

The drug binding fraction $\alpha$, and the equilibrium distribution at each titration position is calculated according to the following formula: $A=C_{b} / C=\left(1-C_{f} / C\right)=\left(A_{f}^{o}-A\right) /\left(A_{f}^{o}-A b^{o}\right) . \mathrm{A}_{f}{ }^{o}$ and $\mathrm{A}_{\mathrm{b}}{ }^{\circ}$ are the measured absorption for the free and fully bound drug at the monitoring wavelength. $r=\alpha \cdot C / C_{D N A}$ and $C_{f}=(1-\alpha) . C$, where $\mathrm{C}_{\mathrm{DNA}}$ is the total concentration of DNA or oligonucleotide titrant at each point. The binding constant value $\mathrm{K}$, was determined by plotting a scatchard plot of $\mathrm{r} / \mathrm{Cf}$ vs $r(22)$.

Competitive binding assay was carried out according to literature (23-26). The fluorescence displacement assay was performed using a Perkin-Elmer LS45 luminescence spectrometer. Emission spectra were measured at $600 \mathrm{~nm}$, using the excitation wavelength $525 \mathrm{~nm}$. The temperature was fixed at $22^{\circ} \mathrm{C}$ throughout the work. Ethedium bromide and Hoechst 33258 were separately mixed with the calf thymus DNA prior to the addition of the test compounds. Calf thymus (30 $\mu \mathrm{l})$ was made up to $2.0 \mathrm{ml}$ using the standard buffer forming a $0.046 \mathrm{mg} / \mathrm{ml}$ prior to its fluorescence intensity measurement. Ethedium bromide (30 $\mu \mathrm{l})$ was then added to it and the fluorescence intensity was re-measured.

Viscometer experiments were performed using an Ubbelohde viscometer (Cannon, USA). The temperature was maintained at room temperature $\left(25^{\circ} \mathrm{C}\right)$ with the aid of a water bath. Calf thymus DNA solution ( $10 \mathrm{ml}$ of $240 \mu \mathrm{g} / \mathrm{ml})$ was placed in the viscometer and allowed to pass through the small capillary tube. The time taken for the sample to pass through was measured by using a digital stop watch. This procedure was repeated but with the addition of varying concentration of $2 \mathrm{MJ}$ and $2 \mathrm{MH}$ to the calf thymus DNA. A volume of 1.3,2.6, 4.0,6.6, 9.33 and $13.33 \mu \mathrm{l}$ containing $30 \mathrm{mg} / \mathrm{ml}$ of the individual compounds were added to $10 \mathrm{ml}$ of the $240 \mu \mathrm{g} / \mathrm{ml}$ calf thymus DNA to give compoundDNA ratio of 1:1, 1:2, 1:3, 1:5, 1:7 and 1:10. Ethedium bromide and Hoechst 33258 were used as positive control representing intercalation and minor groove binding compounds, respectively. The time required for each mixture to pass was recorded. The procedure was performed in triplicate for each sample ratio.

Compound 2MJ, with concentrations $1.25,2.5,6.25,12.5$, $25,37.5,62.5,87.5,125,162.5,200,250,287.5 \mu \mathrm{M}$, was then titrated against the calf thymus DNA and ethedium bromide mixture and the fluorescence intensity reading was taken after each addition until the initial fluorescence intensity value was halved. This process was repeated for $2 \mathrm{MH}$ using concentrations $0.75,1.5,3.75,7.46,14.85,22.33,36.58,50.72,71.42,91.54,111.1$ and $136.36 \mu \mathrm{M}$ of the drug, employing Hoechst 33258 as the competitive substrate in the manner described previously $(21,27)$. The emission intensity was measured at $490 \mathrm{~nm}$ using excitation wavelength of $360 \mathrm{~nm}$.

All the cell lines used for the cytotocity evaluation were between passages 5-9. The cells were cultured in their respective growth medium supplemented with $10 \%$ fetal bovine serum and $1 \%$ penicillin-streptomycin. The colon HCT-116 cells were cultured in McCoy's 5A medium while the liver HepG2 cells were grown in MEM medium. The breast T-47D cells were developed in RPMI-1641 medium. MTT viability assay was performed with slight modifications as described by Mosmann (28). In brief, cells were seeded at 5,000 cell density per well for each 96-well plates in $180 \mu \mathrm{l}$ medium. 2MJ was dissolved in $100 \%$ DMSO as the main stock solution. After an overnight incubation, $2 \mathrm{MJ}$ reagent was added into each well to make the final concentration 100, 50, 25, 12.5, 6.25, 3.12 and $1.56 \mu \mathrm{g} / \mathrm{ml}$. The untreated cells received only DMSO as a negative control. DMSO was serially diluted at concentrations ranging from $1 \%-0.03 \%$. All cells were treated for $48 \mathrm{~h}$. The experiment was repeated twice with four replicates for each concentration. MTT was first prepared as a stock solution in $5 \mathrm{mg} / \mathrm{ml}$ of phosphate buffer saline solution. At the end of the treatment period (48 h), 


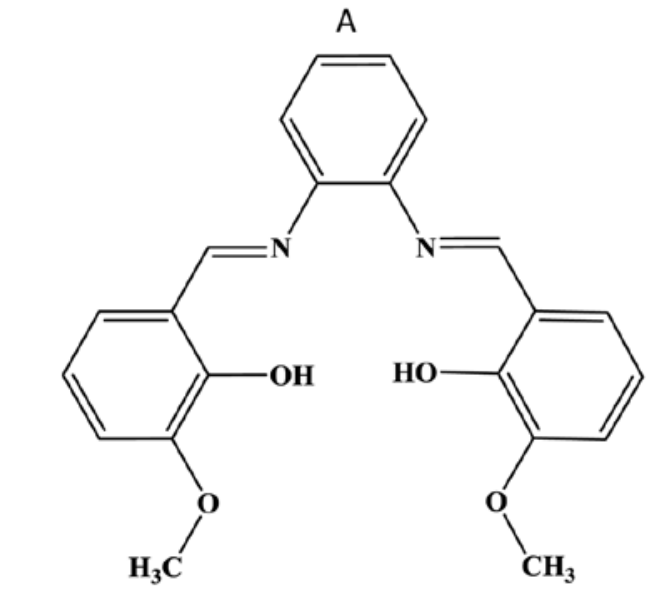

$N, N$-Bis-(2-hydroxy-3-methoxybenzylidene)-1, 2-diaminobenzene (2MJ)
B<smiles>COc1cccc(/C=N/c2cccc(/N=C/c3cccc(OC)c3O)c2)c1O</smiles>

$N, N$-Bis-(2-hydroxy-3-methoxybenzylidene)-1, 3-diaminobenzene (2MH)

Figure 1. (A) $N, N^{\prime}$-Bis-(2-hydroxy-3-methoxybenzylidene)-1, 2-diaminobenzene (2MJ) and (B) $N, N^{\prime}$-Bis-(2-hydroxy-3-methoxybenzylidene)-1, 3-diaminobenzene $(2 \mathrm{MH})$.

$20 \mu 1$ of MTT solution was added to each well. After $4 \mathrm{~h}$ incubation at $37^{\circ} \mathrm{C}$, the medium was removed and $200 \mu \mathrm{l}$ of DMSO was added to the well to dissolve the formazon crystal. After 1 min of shaking, the optical density was recorded using a plate reader (Multiskan Ascent) at $570 \mathrm{~nm}$ for absorbance and $650 \mathrm{~nm}$ as reference filter. This procedure was repeated for $2 \mathrm{MH}$.

All molecular docking simulations were performed by using a PC under Red Hat Linux 9.0 operating system. X-ray crystallographic structure between Hoechst 33258 and a synthetic B-DNA dodecamer of sequence C-G-C-G-A-A-T-T-C-G-C-G (pdb: 8BNA) was used as a model (29). The ligand within the DNA was substituted with $2 \mathrm{MJ}$ and $2 \mathrm{MH}$ crystal structure data (15-19). All the water molecules and heteroatoms were removed from the DNA pdb file. Polar hydrogens were added using Insight II (30) and the charges were assigned from AMBER force fields library using Insight II program (Accelrys Inc.). Each atom was then assigned a solvation parameter based on the affinity of the atom for solvent, and a fragmental volume based on the amount of water that the atom excludes from solvating the surrounding atoms (31). This step was achieved by using ADDSOL utility. Grid parameter file (GPF) was then prepared. Each grid point stores energy of interaction of the corresponding atom type with the rest of the DNA. The evaluation of the binding energy is based on a set of interactions, including van der Waals dispersion forces, electrostatics and hydrogen bonding. A box with dimension of $80 \AA$ x $80 \AA$ x $120 \AA$ was created, to include the entire DNA. A grid spacing of $0.375 \AA$ was used and the pairwise-atomic interaction energy parameters were taken from AutoDock website (http://autodock.scripps.edu). Parameters of 12-6 were set for van der Waals forces, while 12-10 for hydrogen bonds. The distance-dependent dielectric function of Mehler and Solmajer (32) was used. Autodock program version 3.0.5 (33) was used to perform docking.

A rapid energy evaluation through precalculated grids of affinity potential was combined with a variety of algorithms search in order to find a suitable binding position for the ligands on a given DNA site. The program allows the ligands
Table I. The $\mathrm{IC}_{50} \pm \mathrm{SD}$ for each cell line after treatment with different compounds.

\begin{tabular}{lcc}
\hline & \multicolumn{2}{c}{ Compounds } \\
\cline { 2 - 3 } Cell lines & $2 \mathrm{MJ}$ & $2 \mathrm{MH}$ \\
\hline HCT- 116 & $73 \pm 1.5$ & $54 \pm 0.7$ \\
HepG2 & $138 \pm 2.2$ & $98 \pm 0.5$ \\
T-D47 & $205 \pm 1.8$ & $124 \pm 1.1$ \\
\hline
\end{tabular}

to be flexible while the DNA was set to be rigid. This docking technique was carried out using the new empirical free energy function and the Lamarckian Genetic Algorithm parameters (LGA). The cluster tolerance was set at $<1.0 \AA$ and the initial population was limited to 50 randomly placed individuals while the energy evaluations was fixed to the maximum number of $15 \times 10^{5}$ with a maximum number of generations of $2.7 \times 10^{4}$. A mutation rate of 0.02 and a crossover rate of 0.80 with elitism value of 1 were also used. All these parameters are set based on standard protocols (34).

\section{Results}

Spectral results of DNA binding with $2 \mathrm{MH}$ and $2 \mathrm{MJ}$ are presented in Fig. 2A and B respectively. They show the various absorption spectra for compounds $2 \mathrm{MH}$ and $2 \mathrm{MJ}$ before and after mixing with the calf thymus DNA. Both spectra show significant shift and decrease in the UV absorbance spectrum of the compounds following the addition of DNA. Fig. 2A shows the bathochromic $\lambda_{\max }$ value shift from 323 to $347 \mathrm{~nm}$, and the absorption at $\lambda_{\max }$ (hypochromic shift) decrease significantly upon the addition of DNA to $2 \mathrm{MH}$ solution. Fig. 2B shows the bathochromic $\lambda_{\max }$ value for $2 \mathrm{MJ}$ shift from 345 to $351 \mathrm{~nm}$, and a decrease in absorption reading at $\lambda_{\max }$ (hypochromic shift) during addition of DNA to $2 \mathrm{MJ}$ solution. Fig. $2 \mathrm{C}$ and D shows the drop in absorption level upon the addition of DNA to $2 \mathrm{MJ}$ 

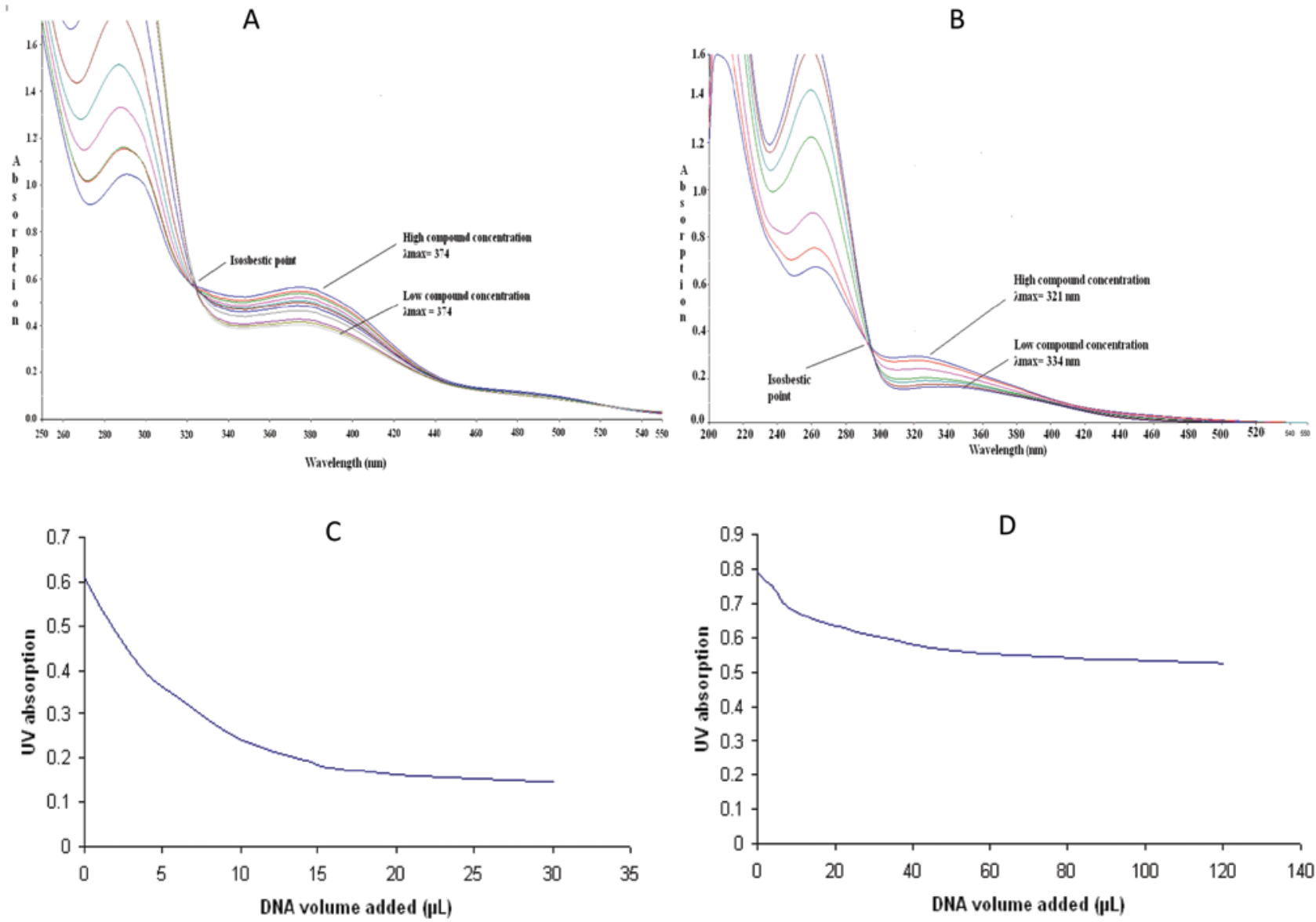

Figure 2. (A) Absorption spectra for $2 \mathrm{MH}$ before adding DNA and after the addition of various amounts of DNA. The figure shows $\lambda_{\max }$ shifting from 323 to $347 \mathrm{~nm}$ (bathochromic shift) and decrease in absorption at $\lambda_{\max }$ (hypochromic shift) upon the addition of DNA. (B) Absorption spectra for 2MJ before adding DNA and after the addition of various amounts of DNA. The figure shows $\lambda_{\max }$ shifting from 345 to $351 \mathrm{~nm}$ (bathochromic shift) and decrease in absorption at $\lambda_{\max }$ (hypochromic shift) upon the addition of DNA, (C) Graph showing the decrease in UV absorption at $\lambda_{\max }$ for $2 \mathrm{MH}$ during the addition of DNA. (D) Graph showing the decrease in UV absorption at $\lambda_{\max }$ for $2 \mathrm{MJ}$ during the addition of DNA.
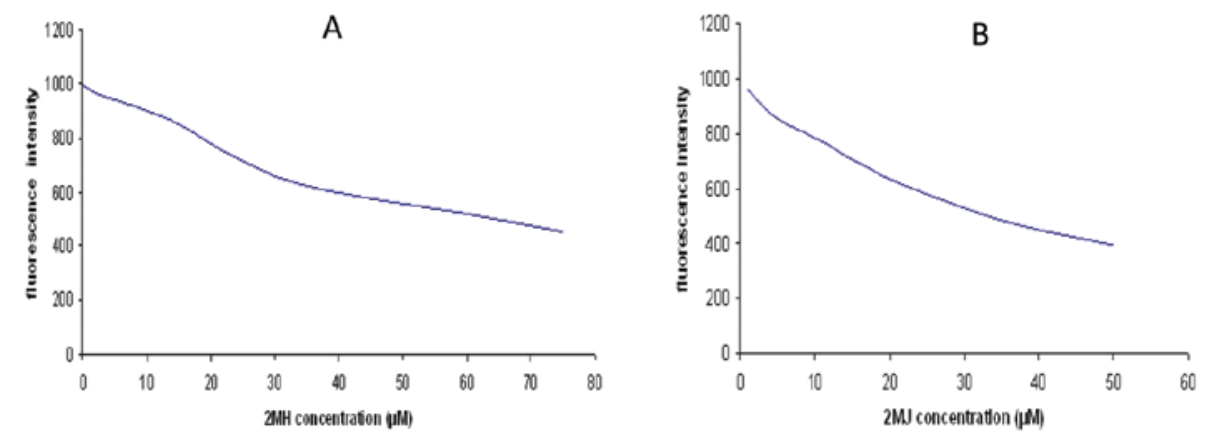

C

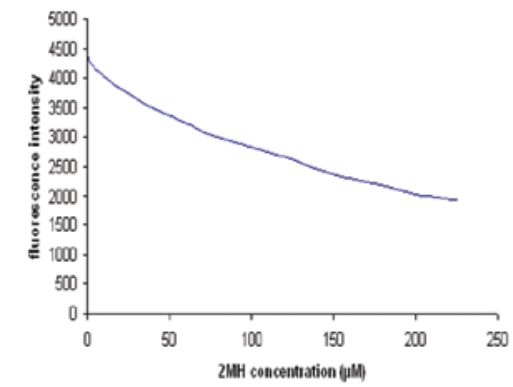

D

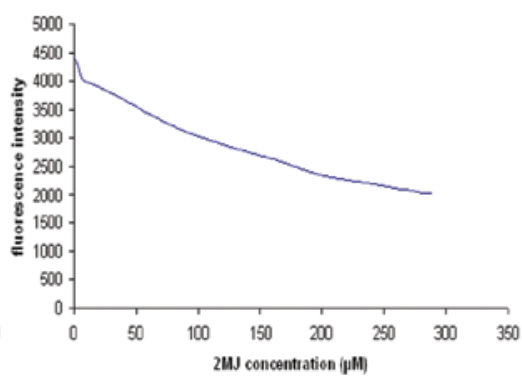

$\mathrm{E}$

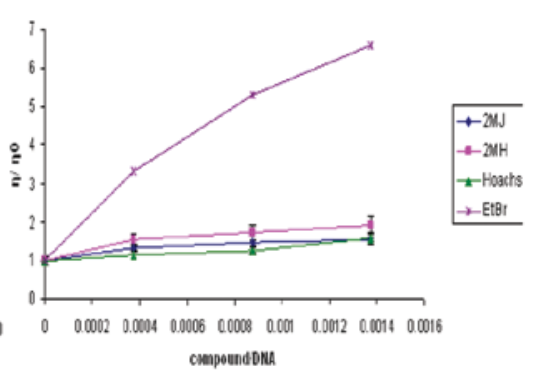

Figure 3. (A) Fluorescence spectra for Hoechst 33258-DNA mixture with the addition of 2MH. (B) Fluorescence spectra for Hoechst 33258-DNA mixture with the addition of 2MJ. (C) Fluorescence spectra for EtBr-DNA mixture with the addition of 2MH. (D) Fluorescence spectra for EtBr-DNA mixture with the addition of 2MJ. (E) Chart showing the increase in viscosity for DNA solution in correspondence to compound addition. 
A Saturation Binding Data 2MJ

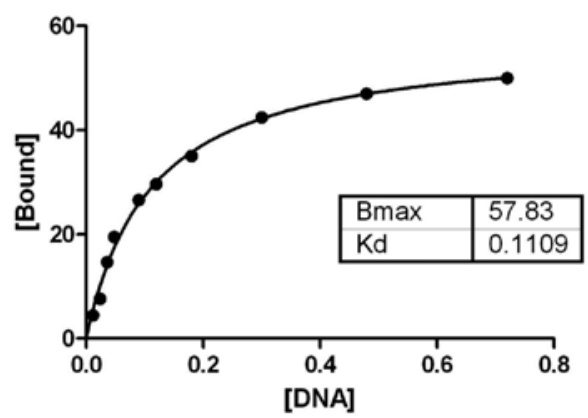

B Saturation Binding Data $2 \mathrm{MH}$

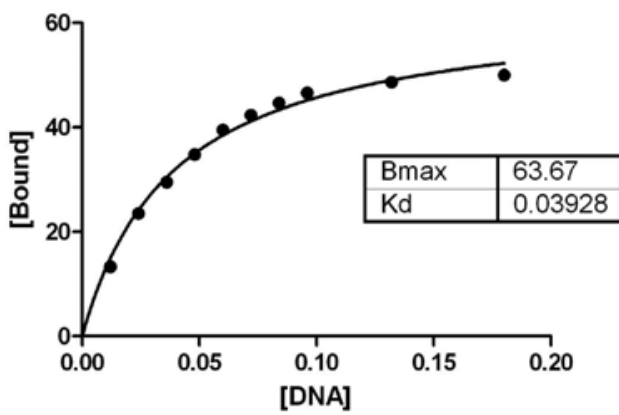

Figure 4. (A) The saturation curve of DNA binding to $2 \mathrm{MJ}$. (B) The saturation curve of DNA binding to $2 \mathrm{MH}$.

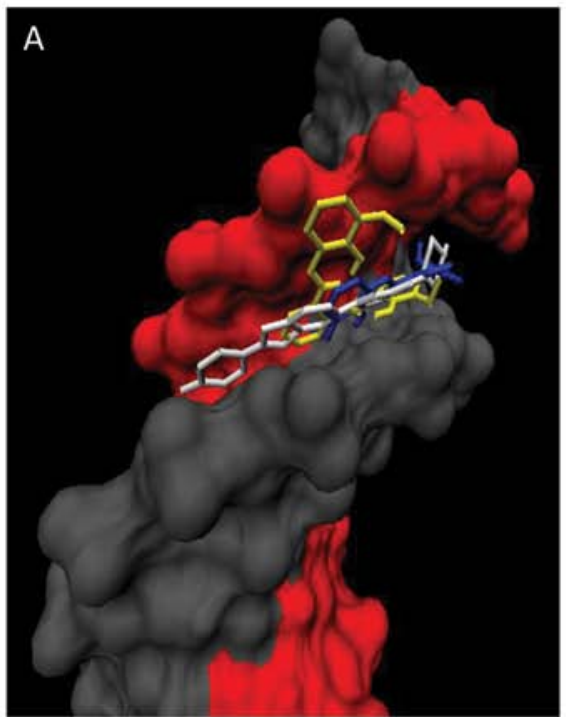

D

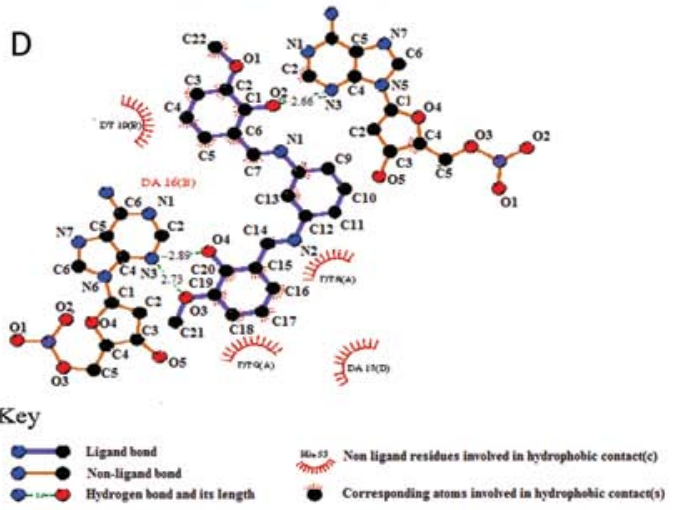

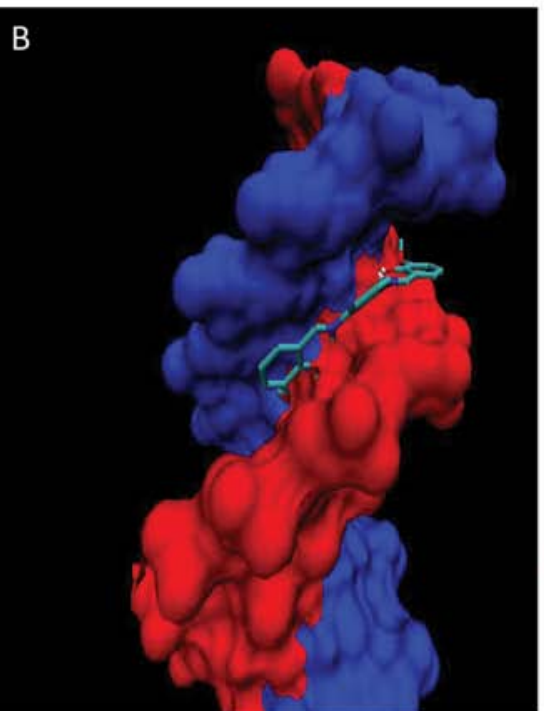

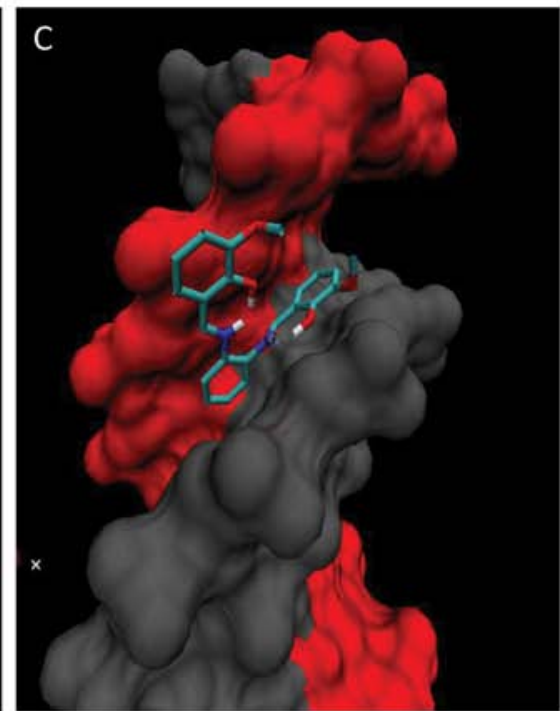

$\mathrm{E}$

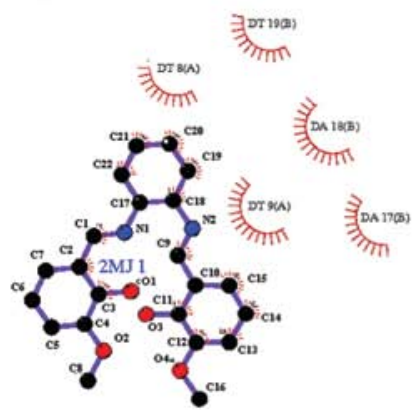

Key

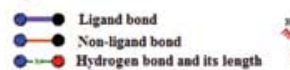

the

Figure 5. (A) The binding of $2 \mathrm{MH}$ (blue), $2 \mathrm{MJ}$ (yellow) and Hoechst (white) to the minor groove region of the DNA. (B) The binding of $2 \mathrm{MH}$ to the minor groove region of the DNA. (C) The binding of 2MJ to the minor groove region of the DNA. (D) The two hydrogen bonds between the atoms O4 and O3 from the compound with N3, Adinosine16. A third hydrogen bond is shown between $\mathrm{O} 2$ on the compound and N3, Adenosine 18 and E. Lack of hydrogen bonding between compound $2 \mathrm{MJ}$ and the DNA is demonstrated.

and $2 \mathrm{MH}$, respectively. Scatchard equation was applied to find the intrinsic coefficient of each compound towards the DNA and their strength of binding, Fig. 4A and B.

In the competitive binding assay utilizing the fluorescence technique, each compound caused a decrease in fluorescence reading of the EtBr-DNA complex. The $\mathrm{Q}$ value, a constant that represents strength of molecule binding, is taken at a concentration where the initial fluorescent intensity is reduced by half (21). The Q values were found to be 173 and $229 \mu \mathrm{M}$ for $2 \mathrm{MH}$ and $2 \mathrm{MJ}$, respectively. Both $2 \mathrm{MJ}$ and $2 \mathrm{MH}$ were able to displace the Hoechst 33258 molecule with $2 \mathrm{MH}$ having slightly higher displacement ability than $2 \mathrm{MJ}$, with their $\mathrm{Q}$ values being 37 and $46 \mu \mathrm{M}$, respectively. Fig. 3 (A and B) and (C and D) show the decrease in fluorescence intensity after the addition of $2 \mathrm{MJ}$ and $2 \mathrm{MH}$ on the EtBr-DNA and Hoechst 33258-DNA mixtures, respectively. 
The results of the viscosity experiment show that $2 \mathrm{MH}$ and $2 \mathrm{MJ}$ can cause an increase to the DNA solution viscosity. This indicates a binding interaction between the nucleic acid and the two compounds. The viscosity was calculated using the following derived from Poiseuille's law (35). $\eta_{s p}=\eta_{r}-1=t-t_{o} / t_{o}$. Where $\eta_{\text {sp }}$ represents the specific viscosity and $t_{o}$ is the time needed for elution of the solvent alone and $t$ is the elution time needed for the solution. By this equation, the viscosity after addition of each compound was calculated. Fig. 3E shows the result of the viscometry studies for $2 \mathrm{MJ}$ and $2 \mathrm{MH}$. The slope measurement for $2 \mathrm{MH}$ is significantly higher than $2 \mathrm{MJ}$ indicating stronger DNA binding. The data are presented as $\eta / \eta_{0}$ vs compound/DNA concentration ratio. $\eta$ presents the viscosity for DNA-compound mixture, while $\eta_{0}$ represents viscosity for DNA solution alone. The results of the viscosity experiments show that $2 \mathrm{MH}$ and $2 \mathrm{MJ}$ do not cause significant increase to the DNA solution viscosity compared to the well established intercalator ethedium bromide which acts as the control for this experiment (Fig. 3E). Hoechst 33258 reagent is used as a positive control to represent a minor groove binder. The viscosity reading for the Hoechst 33258 compound is similar to that of $2 \mathrm{MJ}$ and $2 \mathrm{MH}$.

The $\mathrm{IC}_{50}$ for compound $2 \mathrm{MJ}$ and $2 \mathrm{MH}$ when exposed to the HCT-116 cell line were 73 and $54 \mu \mathrm{M}$, respectively. In the HepG 2 cell line, the $\mathrm{IC}_{50}$ for compound $2 \mathrm{MJ}$ and $2 \mathrm{MH}$ were 138 and $98 \mu \mathrm{M}$, respectively, while in the T-D47 breast cancer cells, the values were 205 and $124 \mu \mathrm{M}$ for $2 \mathrm{MJ}$ and $2 \mathrm{MH}$, respectively (Table I).

Molecular docking results confirmed the findings in the spectroscopy analysis. Fig. 5A-C shows that both compounds were able to bind at the same location where Hoechst resides. The free energy of binding were -9.61 and $-7.38 \mathrm{kcal} / \mathrm{mol}$ for $2 \mathrm{MH}$ and $2 \mathrm{MJ}$, respectively, indicating that $2 \mathrm{MH}$ has a stronger affinity for the DNA at this site compared to 2MJ. Fig. 5D and E shows the result of the docking analysis. The figures reveal that three hydrogen bonds can be formed between the DNA and $2 \mathrm{MH}$. However, no hydrogen bond formation occurs between $2 \mathrm{MJ}$ and the deoxyribonucleotide.

\section{Discussion}

Since the discovery of minor groove binders, a number of researchers have developed a variety of alkylating groove binders by anneling classical chemotherapeutic compounds to MGBs. This has demonstrated improved potency and better selectivity (36).

The number of MGBs that have been discovered so far is limited and there is a constant effort to find better MGBs that can also be easily synthesized. Schiff bases that harbor metal complexes have been shown to have the ability to interact with the nucleic acid $(11,12)$. A number of these Schiff bases studied, can cause DNA strand breaks (14). However, the study of metalfree Schiff base interaction with the nucleic acid is still lacking and research on their anti-tumor potential is not well established. $2 \mathrm{MJ}$ and $2 \mathrm{MH}$ are two novel Schiff base structural analogues, which differ in their 2-hydroxy-3-methoxybenzylidene binding position. 2MJ (Fig. 1A) has its 2-hydroxy-3-methoxybenzylidene substructure located at the 1 and 2 positions of its diaminobenzene unit, while $2 \mathrm{MH}$ (Fig. 1B) has this moiety located at the 1 and 3 positions making its structure wider than the former. The results from the UV spectroscopy and viscometery analysis clearly indicate that $2 \mathrm{MH}$ and $2 \mathrm{MJ}$ can bind to the DNA with good binding strength.

In the displacement assay, $2 \mathrm{MJ}$ and $2 \mathrm{MH}$ were able to displace Hoechst 33258 from its site of residence within the DNA, indicating that these agents are able to bind to the nucleic acid in its minor groove region. However, based on their calculated $\mathrm{Q}$ values, $2 \mathrm{MH}$ shows to be a better MGB than $2 \mathrm{MJ}$ with its $Q$ value being more than $40 \%$ lower than that for $2 \mathrm{MJ}$.

To a limited extent, both compounds were also able to displace EtBr suggesting a trifling intercalation reaction as well. The lack of significant intercalation reaction is further evidenced when comparing their overall $\mathrm{Q}$ values at the respective sites. Both compounds were found to have more than 5-fold affinity towards the minor groove region compared to the intercalation sites. This suggests that these agents are better MGBs rather than intercalators. The poor intercalation reaction exhibited by $2 \mathrm{MJ}$ and $2 \mathrm{MH}$; with the latter being more prominent, is not a surprise. This is because they are short of sufficient number of flat aromatic structures to form adequate electrostatic attraction with the bases in the narrow spaces between the adjacent DNA base pairs (4). The lack of significant cytotoxicity activity by $2 \mathrm{MH}$ and $2 \mathrm{MJ}$ is a typical characteristic of MGBs given that this region is not frequented by important enzymes such as DNA polymerase and topoisomerase. However, taken as a whole, the extent of cytotoxic activity was significantly higher for $2 \mathrm{MH}$ compared to $2 \mathrm{MJ}$. This may be due to the stronger DNA binding ability exhibited by $2 \mathrm{MH}$ and its minor intercalative reaction which may interfere with the functioning of the said regulatory proteins that reside in the major groove region.

The wide angle of curvature of the $2 \mathrm{MH}$ has demonstrated significantly improved binding to the DNA compared to its isomeric partner $2 \mathrm{MJ}$. The spectroscopic data, viscometry analysis and molecular modeling study strongly support this finding. In the modeling data, the result shows that both $2 \mathrm{MJ}$ and $2 \mathrm{MH}$ can fit into the minor groove region at the site where Hoechst 33258 can reside (Fig. 5A). However the finding also shows that part of $2 \mathrm{MJ}$ substructure appears to be protruding out of the groove region as shown in Fig. $5 \mathrm{C}$. $2 \mathrm{MH}$ on the contrary appears to reside snuggly into the groove with all its structure lying in parallel within the walls of the minor groove region (Fig. 5B). The modeling result also shows that $2 \mathrm{MH}$ can form 3 hydrogen bonds at its $\mathrm{O} 4$ and $\mathrm{O} 3$ atoms with $\mathrm{N} 3$ of adenosine 16 of one DNA strand, and its $\mathrm{O} 2$ atom with $\mathrm{N} 3$ atom of adenosine 18 of the complementary DNA strand (Fig. 5D). Moreover, the modeling data also show that $2 \mathrm{MH}$ can form good hydrophobic contact with the deoxyribonucleotide. However, apart from hydrophobic interaction with the DNA, 2MJ appears to lack the ability to form any viable hydrogen linkages with the nucleic acid (Fig. 5E).

The findings of this work support previous studies which show that good groove binders are crescent in shape and the ones that have wider angle of curvature are better MGBs (36). However, the angle of curvature of the molecule must complement the DNA curvature. This can allow better interaction with hydrogen bond acceptors and donors that exists at the point of contact between both ligand and DNA. However, if the curve is too narrow, it may prevent the ligand from penetrating deep enough into the walls of the groove. This may also limit hydrophobic interaction hence reducing binding efficiency. 
Although $2 \mathrm{MH}$ and $2 \mathrm{MJ}$ are relatively neutral MGBs, they are still potent enough to cause significant DNA binding. Minor groove regions that are rich in AT sequences emit strong negative charges due to the presence of phosphate groups. Hence, positively charged molecules tend to be attracted to the negative charged AT sequence (37). However, agents that are devoid of any charge still have the ability to bind to the MGR but the binding strength is significantly lower (38).

Taken together, this study reveals diaminobenzene Schiff base compounds that are devoid of metal cations can bind to the DNA. The site of ligand binding is mainly via the minor groove and to lesser extent, the major groove. The annular shape of the molecule and its degree of curvature influences the DNA-binding affinity particularly to the minor grove region. The work also shows that the two Schiff bases, $2 \mathrm{MJ}$ and $2 \mathrm{MH}$ are non-cytotoxic.

\section{Acknowledgements}

We would like to thank Dr Shafida A. Hamid (Universiti Sains Malaysia) and Dr Salizawati Mohd. Salhimi (Universiti Sains Malaysia) for their valuable support. This work was funded by research grants from the Universiti Sains Malaysia (RU: 1001/ PFARMASI/811144).

\section{References}

1. Neidle S: DNA minor-groove recognition by small molecules. Nat Prod Rep 18: 291-309, 2001.

2. Nelson EM, Tewey KM and Liu LF: Mechanism of antitumor drug action: poisoning of mammalian DNA topoisomerase II on DNA by 4'-(9-acridinylamino)-methanesulfon-manisidide. Proc Natl Acad Sci USA 81: 1361-1365, 1984.

3. Sinha R, Islam MM, Bhadra K, Kumar GS, Banerjee A and Maiti M: The binding of DNA intercalating and non-intercalating compounds to A-form and protonated form of poly $(\mathrm{rC}) \cdot \operatorname{poly}(\mathrm{rG})$ : Spectroscopic and viscometric study. Bioorgan Med Chem 14: 800-814, 2006.

4. Williams TT and Barton JK: Charge transport in DNA. In: DNA and RNA Binders: from small molecules to drugs. Demeunynck M, Bailly $\mathrm{C}$ and Wilson WD (eds). Wiley-VCH, Weinheim, Vol 1, p146, 2003.

5. Dadgarnezhad A, Sheikhshoaie I and Baghaei F: Corrosion inhibitory effects of a new synthetic symmetrical Schiff-base on carbon steel in acid media. Anti-Corrosion Methods Materials 51: 266-271, 2004.

6. Ma H, Chen S, Niu L, Zhao S, Li S and Li D: Inhibition of copper corrosion by several Schiff bases in aerated halide solutions J Appl Electrochem 32: 65-72, 2002.

7. Nair R, Shah A, Baluja S and Chanda S: Synthesis and antibacterial activity of some Schiff base complexes. J Serb Chem Soc 71: 733-744, 2006.

8. Morad FM, El Ajaily MM and Gweirif SB: Preparation, physical characterization and antibacterial activity of Ni (II) Schiff base complex. J Sci Applicat 1: 72-78, 2007.

9. Hou H, Zhu J, Liu Y and Li Q: Antibacterial activity of a kind of novel Schiff base and its 3d,4f complexes. Acta Physicochim Sin 23: 987-992, 2007.

10. Kuz'min VE, Lozitsky VP, Kamalov GL, Lozitskaya RN, Zheltvay AI, Fedtchouk AS and Kryzhanovsky DN: Analysis of the structure - anticancer activity relationship in a set of Schiff bases of macrocyclic 2,6-bis(2- and 4-formylaryloxymethyl) pyridines. Acta Biochim 47: 867-876, 2000.

11. Ye Y, Hu J, He L and Zeng Y: Surface-enhanced Raman spectroscopy of some Schiff base complexes and their interaction with DNA. Vibr Spectrosc 20: 1-4, 1999.

12. Wang B-D, Yang Z-Y, Qin W, Cai T-K and Crewdson P: Synthesis, characterization, cytotoxic activities, and DNA-binding properties of the La(III) complex with naringenin schiff-base. Bioorg Med Chem 14: 1880-1888, 2006.
13. Vijayalakshmi R, Kanthimathi M, Subramanian V and Nair BU: Interaction of DNA with $\left[\mathrm{Cr}(\mathrm{Schi} ;\right.$ base $\left.)\left(\mathrm{H}_{2} \mathrm{O}\right)_{2}\right] \mathrm{ClO}_{4}$. Biochim Biophys Acta 1475: 157-162, 2000.

14. Silveira VCd, Luz JS, Oliveira CC, Graziani I, Ciriolo MR and Ferreira AMdC: Double-strand DNA cleavage induced by oxindole-Schiff base copper(II) complexes with potential antitumor activity. J Inorg Biochem 102: 1090-1103, 2008.

15. Al-Douh MH, Al-Fatlawy AA and Abid OH: Synthesis and characterization of some 2-(N-Benzoyl-N-pyrid-4-yl aminobenzyl)-aminobarbituric acids via Schiff's bases. Hadh Studies Res 4: 37-49, 2003.

16. Al-Douh MH, Al-Fatlawy AA and Abid OH: Synthesis and characterization of some 2-(N-benzoyl-N-pyrid-2-yl aminobenzyl)aminobarbituric acids via N-benzylidene pyridine-2-amines. J Nat Appl Sci 8: 181-194, 2004.

17. Al-Douh MH, Al-Fatlawy AA and Abid OH: Synthesis and characterization of 2-(N-benzoyl-N-pyrid-3-yl aminobenzyl)aminobarbituric acids via $\mathrm{N}$-benzylidene pyridine-3-amines. Fac Sci Bull 16: 83-94, 2003.

18. Al-Douh MH, Hamid SA, Osman H, Ng SL and Fun HK: 6 , 6'-dimethoxy-2, 2'-[m-phenylene bis(nitrilomethylidyne)]diphenol. Acta Crystallogr 63: O3570-O3571, 2007.

19. Al-Douh MH, Hamid SA, Osman H, Kia R and Fun HK: 2-amino-N-(2-hydroxy-3-methoxybenzylidene) aniline. Acta Crystallogr 64: O1201-O1202, 2008.

20. Stokke T and Steen HB: Multiple binding modes for Hoechst 33258 to DNA. J Histochem Cytochem 33: 333-338, 1985.

21. Fox KR: Drug-DNA Interaction Protocols. Humana Press, NJ, 1997.

22. Jenkins TC: Optical absorbance and fluorescence techniques for measuring DNA-drug interactions. In: Drug-DNA Interaction Protocols. Vol. 90. Fox KR (ed). Humana Press, NJ, pp195-218, 1997.

23. Morgan AR, Lee JS, Pulleyblank DE, Murray NL and Evans DH: Ethidium fluorescence assays. Part 1. Physicochemical studies. Nucleic Acids Res 7: 1979.

24. Roche CJ, Thomson JA and Crothers DM: Site selectivity of daunomycin. Biochemistry 33: 926-935, 1994.

25. Haq I, Lincoln P, Suh D, Norden B, Chowdhry BZ and Chaires JB: Interaction of .delta.- and .lambda.-[Ru(phen)2DPPZ]2+ with DNA: a calorimetric and equilibrium binding study. J Am Chem Soc 117: 4788-4796, 1995.

26. Chaires JB, Dattagupta N and Crothers DM: Studies on interaction of anthracycline antibiotics and deoxyribonucleic acid: equilibrium binding studies on the interaction of daunomycin with deoxyribonucleic acid. Biochemistry 21: 3933-3940, 1982.

27. Peberdya JC, Malinab J, Khalide S, Hannond MJ and Rodger A: Influence of surface shape on DNA binding of bimetallo helicates. J Inorg Biochem 101: 1937-1945, 2007.

28. Mosmann T: Rapid colorimetric assay for cellular growth and survival: application toproliferation and cytotoxicity assays. J Immunol Methods 65: 55-63, 1983.

29. Pjura PE, Greskowiak K and Dickerson RE: Binding of Hoechst 33258 to the minor groove of B-DNA. J Mol Biol 197: 257-271, 1987.

30. Accelrys Inc.: Insight II Journal 2000.

31. Marrone TJ, Luty BA and Rose PW: Discovering high-affinity ligands from the computationally predicted structures and affinities of small molecules bound to a target: a virtual screening approach. Perspect Drug Discov Design 20: 209-220, 2000.

32. Mehler El and Solmajer T: Electrostatic effects in proteins: Comparison of dielectric and charge models. Protein Engineering 4: 903-910, 1991.

33. Morris GM, Goodsell DS, Halliday RS, et al: Automated docking using a Lamarckian genetic algorithm and an empirical binding free energy function. J Comput Chem 19: 1639-1662, 1998.

34. Kulys J and Ziemys A: A role of proton transfer in peroxidecatalyzed process elucidated by substrates docking calculation. BMC Struct Biol 1: 1-6, 2001.

35. Satyanarayana S, Dabrowik JC and Chaires JB: Tris (phenanthroline)ruthenium(II)enantiomer interactions with DNA: Mode and specificity of binding. Biochemistry 32: 2573-2584, 1993.

36. Neidle S: Nucleic acid Structure and Recognition. Oxford University Press, New York, NY, 2002.

37. Constant J-F and Demeunynck M: Design and studies of a basic targeting drugs. In: Small Molecule DNA and RNA Binders: from synthesis to nucleic acid complex. Demeunynck M, Bailly C and Wilson WD (eds). Wiley-VCH, Weinheim, Vol 2, p247, 2003.

38. Chen Y-H, Yang Y and Lown JW: Design of distamicin analogues to probe the physical origin of the antiparallel side by side oligopeptide binding motif in DNA minor groove recognition. Biochem Biophys Res Commun 220: 213-218, 1996. 